\title{
WORK STRESS, PAY SATISFACTION, PSYCHOLOGICAL EMPOWERMENT AND ORGANISATIONAL COMMITMENT AMONG ACADEMIC STAFF
}

\author{
AMER DARUS \\ FARAH LINA AZIZAN \\ FAIS AHMAD \\ School of Business Management \\ Universiti Utara Malaysia
}

\begin{abstract}
This study investigated the mediating effect of psychological empowerment on the relationship between work stress, pay satisfaction, and organisational commitment among academic staff in public universities. A total number of 297 academics responded to this study and Statistical Package Software for Social Science (SPSS) Version 21.0 was used to analyse the collected data. The results indicated that work stress is associated with organisational commitment, whereas pay satisfaction, psychological empowerment, and organisational commitment have significant relationships with each other. Furthermore, multiple regression analysis revealed that psychological empowerment partially mediated on the relationship between pay satisfaction and organisational commitment. It is recommended that future research could further extend by including non-academic staff as well.
\end{abstract}

Keywords: Organisational Commitment, Work Stress, Pay Satisfaction, Psychological Empowerment

\section{Introduction}

Nowadays, organisations are facing challenges and opportunities due to the constantly changing world of business. In order to improve productivity of organisations, human resource is an important asset of the organisation (Malik, Nawab, Naeem \& Danish 2010). Every organisation aims to have committed employees toward the fulfillment of the organisational goals. Negative impact will lead to a stressful condition when employees are incapable to provide full 
of commitment as they experience dissatisfaction in their job process specifically in educational institutions (Gupta \& Gehlawat, 2013). It is difficult for organisations to shift forward in achieving their objectives without productive and committed individuals. Malaysia needs a work force that possesses high commitment, productivity, progressiveness, competitiveness, and efficient in its mission to achieve the Vision 2020 targets (Ismail, 2012). Therefore, this is a serious issue that organisations must take note because organisational efficiency depends on employee's productivity and commitment. Furthermore, there is very little research done to identify factors that impact organisational commitment among academics (Chang \& Choi, 2007; Chen et al., 2007; Freund, 2005; Obeng \& Ugboro, 2003).Therefore, this study investigated work stress, psychological empowerment and pay satisfaction as factors affecting commitment among academician toward public universities in Malaysia.

According to Lew (2011), teaching quality is important in order to create higher quality and competitive graduates. In order to achieve the required level of teaching quality, the Dean and Head of Department need to shape the academicians' attitudes by guiding them into sound practices (Bogler \& Somech, 2004; Dee et al., 2003). It is also important to know about the relationship between job satisfaction, organizational, commitment and the retention of satisfied employees (Ismail, 2012). High employee retention would eventually benefit the organisation, as it is expected that the higher level of job satisfaction among employees, the higher their commitment to the organisation.

The demand of meeting key performance indicators (KPI) from universities and the demand from stakeholders to produce quality and employable graduates have put Malaysian academic staff facing a big challenge (MoHE, 2012). With these demands and the quick growth in education sector in Malaysia, academicians are facing more stress. This effect of stress is supported by Nilufar, Abdullah, Fie, and Alam (2009) in their studies that showed work stress influences work satisfaction among academicians in public institutions. Academicians who always experience stress and are unsatisfied with their work will have negative influence on their performance, work quality and also commitment toward the organisation (Adebiyi, 2013; Barkhuizen et al., 2014; Hadi et al., 2015).

It is well known that one of the motivating factors in continued commitment of employees is the economic factor. Pay is a major factor behind recruitment and retention problems in the education sector, 
particularly for staff whose expertise is valued in the private sector such as information technology, computing, law, and accountancy. In addition, according to Malik et al. (2010), and Milkovich and Newman (2004), pay is a well-known important factor along with other rewards provided by an organisation for employee's contribution toward achieving organisational goals. Pay is also commonly used as incentive for enhancing performance and for retaining the most excellent employees (Galleta et al., 2011; Gardner et al., 2004; Onn, 2012). When performance is rewarded and academicians demand salary is high, it will make talented academicians remain satisfied and committed to their respective universities (Solomon \& Podgursky, 2001). This is also supported by Awang and Ahmad (2010) and Mustapha (2013), found who a significant relationship between pay satisfaction and staff commitment toward the organisation.

In general, academicians will be satisfied and committed to the organisation when they recognize that the existing salary scheme and also opportunity for promotion are sufficiently provided by the universities (Tella et al., 2007; Siddique et al., 2011). With the improvement of overall job satisfaction of academicians, there will be a low turnover rate improved ability in and attracting new competent staff to join the university and fulfilling national demands (Hafiz et al., 2014; Noordin \& Jusoff, 2009).

According to Krishna (2007), Liu, Fellows, and Chiu (2006), McShane and Von Glinow (2010), and Nabila (2008), the increasing perception of work empowerment promotes increasing organisational commitment. When the superior empowers employees by giving an opportunity to make decisions about their work methods, pace, and efforts, they are able to influence the organisational outcome, and this will automatically improve staff commitment (Onn, 2012).

Chen and Chen (2008) revealed that in order to increase employee commitment, the organisation should provide them with ample opportunities to take on more responsibilities and perform more challenging tasks. Employees who perceive that they have more psychological empowerment attached with the organisation are more likely to be committed to the organisation. Furthermore, employees who are not committed to organisation would not assist in accomplishing the organisational objectives if they feel that they are not empowered enough. 
The next section emphasises on a review of research concepts and theories associated to variables of this study. Hypotheses development supported by previous scholars is also discussed. Next the following parts comprises the research methodology applied by the researchers. The finding of this study is then showed and explained. Finally, the last section offers the discussion leading to the conclusion, limitation, practical and theoretical contribution of the study, as well as suggestion for future research.

\section{Literature Review}

\section{Organisational Commitment}

According to past literature, most of the developed theories or models of organisational commitment are based on attitudinal and behavioural aspects. The former aspect is associated with employees' emotional or psychological attachment toward their employers (Sheldon, 1971). Besides, Meyer and Allen (1987) grouped organisational commitment according to three approaches which are affective, continuance and normative commitment types. Affective commitment refers to the employee's emotional desire involved in gaining recognition with and contributing toward the organisation, while continuance commitment is the employee's perception for gratitude of the remuneration to remain in the organisation against the supposed leaving cost. Meanwhile, normative commitment is an effect related to the employee's feeling of responsibility to remain in the organisation, derived from individual values and customs.

\section{Work Stress}

In spite of the increasing literature on work stress, confusion and conflict are still main factors in terms of stress. As a result, Selye (1976) demonstrated that stress is action to react and give feedback for any challenge and defy experience, whereas, experience leads to demand based on the individual (Kahn et al., 1964). One of the attributes of environment which distorts and causes significant threat to the individual (French et al., 1982) is individual awareness for being unable to deal effectively with the demands placed upon them (Lazarus, 1991). Based on researcher understanding, stress comprises two components; cognitive interpretation and stressor. Definition of stress should have these components before it is able to be called "stress". Stress can be interpreted as a person being able to predict an 
upcoming event (cognitive interpretation) and take action to react or respond to any changes in the environmental variables (stressor) as in part of stress.

Recently, Ashari, Ahmad \& Rahman (2005) in their study among academic staff found that the relationship between work stress and commitment exists, where role conflict and role ambiguity are seen as contributing factors. A study on university staff in South Africa revealed that work stress plays a role in decreasing organisational commitment (Khairuddin \& Makhbul, 2011). Furthermore, Michael, Court \& Petal et al. (2009) indicated that work stress has negative influence on affective commitment. This means that the level of affective commitment tends to increase when stress decreases.

Nonetheless, similar studies were conducted on workplace stress and work fatigue among academicians by Adebiyi (2013) and Barkhuizen et al. (2014). Stress among academicians can be caused by many factors which do not involve academic workload. However, O'Laughin and Bischoff (2005) in their study suggested that women have reported higher levels of stress as compared to men. Conversely, Purvanova and Muros (2010) revealed that both female and male employees experience equal stress levels. Even so, most studies showed in many organisations, work stress is not a new phenomenon. Furthermore, Adebiyi (2013), Ashari et al. (2005), and Gillespie, Walsh, Winefield, Dua \& Stough (2001) highlighted that when work stress increases, organisational commitment would decrease. This means employees who experience stress will not be fully committed to the organisation.

\section{Pay Satisfaction}

Lawler (1971) opined that pay satisfaction is the distinction between amount of salary a person gets and a person's expectation about the amount of salary he should get. The model of determinants in pay satisfaction was built by Lawler (1971). His model identified pay satisfaction based on two factors which are; A is ascertained amount of salary that one should get and, B is ascertained amount of salary one receives. When $A$ is equal to $B$, the employee will feel satisfied. When $A$ is more than $B$, the employee will feel dissatisfied. Meanwhile, when $B$ is greater than $A$, the employee will feel discomfort, guiltiness, and sense of unfairness. In return for employee contribution toward management target achievement, salary is believed to be a vital element among the reward given by the organisation (Heneman \& Judge, 2000; Vandenberghe \& Tremblay, 2008). 
According to Dulebohn and Martocchio (1998), pay satisfaction is clear information about payment policy and confidence with salary system efficiency, which are related to affective commitment. It is also related to pay satisfaction by overall work achievement, encouragement and performance. There are four types of equity in designing a pay system; internal equity, external equity, private equity and procedural justice that are important to the organisation (Terpstra, Hondree \& Andree 2003; Tremblay, Inman, \& Willms, 2000). When satisfaction of pay increases, such as in pay structure and pay plan efficiency, it will lead to increase in organisational commitment (Malik et al., 2010; Tella et al., 2007). Employees who are satisfied in their work will show positive attitude (Jain, Jabeen, Mishra \& Gupta 2007).

Besides, pay satisfaction and normative commitment are significantly association with each other (Takleab, Takaeyeh \& Taylor 2005). Research by Awang and Ahmad (2010), and Mustapha (2013) found that perception on pay structure understanding is positively related to affective commitment. It means that when employees are satisfied with the reward given, their commitment to the organisation will increase.

\section{Psychological Empowerment}

According to Thomas and Velthouse (1990), empowerment is crucial in encouraging employees. Empowerment is related to the changes in cognitive variables. They declared their model of motivational or psychological approach to empowerment focuses on the individual's psychological and cognitive states experienced in their work. This theory places importance on the perception of employees of their power in coping with events and people they confront at the workplace. It also manages to provide communication openness, goaloriented settings, and pertinent feedback to increase commitment and satisfaction. Thomas and Velthous (1990) categorised empowerment into four dimensions, consisting of meaning, competence, selfdetermination, and impact.

As cited in Khany and Tazik (2015), Thomas and Velthous's model have been used in different studies. For example, Carless (2004) tested the model in a study in which psychological empowerment mediates the relationship between psychological climate and job satisfaction. The finding found that meaning and competence were largely responsible for the mediating effect between psychological climate and job satisfaction. Furthermore, Dee et al. (2003) resealed that meaning, self-determination, and impact dimensions have positive 
effects on teachers' level of organisational commitment. Likewise, they indicated that empowered teachers with increased task motivation, improved feeling of meaning, and strong organisational commitment are the basis for a dynamic school environment. Thus, previous studies had shown that empowerment could be an important way for enhancing commitment, and reducing stress and turnover intention. Furthermore, study by Leeand Nie(2014) revealed that four dimensions of psychological empowerment; meaning, competence, autonomy, and impact have a mediation role in the relationship between workrelated outcome in terms of organisational commitment and job satisfaction, and teacher's perceptions of immediate supervisor's empowering behaviour. However three dimensions, namely meaning, autonomy, and impact mediate the relationship between teacher's perceptions on principal's empowering behaviour and their work related outcome. Additionally, Lee and Nee (2014), and Khany and Tazik (2015) argued that, more empirical research efforts are needed to clarify the relationship between job satisfaction and psychological empowerment. Several findings from previous studies had revealed strong positive correlation between job satisfaction and two dimensions of psychological empowerment, namely meaning and self-determination, and inconsistent correlations with competence and impact dimensions (Wang \& Lee, 2009).

Besides, Fornes and Rocco (2004) asserted that commitment can arise through empowerment. It can produce psychological states that directly lead to positive outcomes for the organisation, willingness to give extra role performance, increased job satisfaction, and enhanced motivation. With empowering, the organisation can improve its productivity as this process can increase employee motivation in terms of offering them with the opportunity to gain intrinsic rewards from their work, such as greater sense of accomplishment and feeling of importance. This is instinctively linked to the employees' commitment. A study by Liu et al. (2006) opined that when the perception of work empowerment increases, employees' organisational commitment increases accordingly. The findings showed the factors of access to opportunity and resources, could increase self-efficacy of employees to feel empowered, motivated, and committed before directly leading to increased work performance and effectiveness (Noraida, Shaladdin, Fauziah \& Munair 2010).

Likewise, Onn (2012) claimed that in order to increase employee commitment to the organisation, organisations should provide them with substantial opportunities to obtain more responsibilities 
and perform challenging work. Employees will feel empowered when they are given the responsibility to undertake tasks and more responsibilities to give opinion and make decisions at work. Consequently, they are more willing to remain with the organisation and work harder (McShane \& Von Glinow, 2010; Spreitzer, 1995).

Laschinger and Havens (1996), and Laschinger,Wong, MacMahon \& Kaufman (1999) found that work stress is negatively related to psychological empowerment. Individuals who are highly stressed will experience reduced meaning in their work and selfdetermination. This eventually will lead to decreased commitment toward organisation. According to Thomas and Tymon (1994), when things do not go as planned, employees will feel highly stressed which leads to feeling that their work is not meaningful to them.

However, Bowen and Lawler (1992) stated that payments based on performance would contribute to empowerment. Their findings showed little evidence to confirm that pay satisfaction is significantly associated to psychological empowerment. They argued that organisations that are interested in empowering their employees and creating a committed workforce should develop a system which would reward employees' performance equally. McElroy (2001) argued that providing high reward extrinsically, could lead to highly intrinsical rewards which would make employees feel important to the organisation. Consequently, it will motivate employees to give more effort to the organisation. Besides, Disch, Edwadson \& Adwon (2004) mentioned that if employees believe and are satisfied with the reward and benefits, they would often feel deeply connected with their work.

Based on previous findings that showed a relationship exists between work stress, pay satisfaction, and commitment (Khairuddin \& Makhbul, 2011; Mustapha, 2013), a relationship between work stress, pay satisfaction, and empowerment (Laschinger et al., 1999; McElroy, 2001) and a relationship between empowerment and commitment (Noraida et al., 2010), it can be assumed that empowerment could be a mechanism that will increase commitment to address the issues of work stress and pay satisfaction. This could lead to higher commitment, lower rates of absenteeism, and intention to leave as well.

Therefore, the seven research hypotheses developed for this study are as follows: 
H1: Work stress has a significant impact on organisational commitment.

H2: Pay satisfaction has a significant impact on organisational commitment

H3: Psychological empowerment has a significant impact on organisational commitment.

H4: Work stress has a significant impact on psychological empowerment.

H5: Pay satisfaction has a significant impact on psychological empowerment.

H6: Relationship between work stress and organisational commitment is partially mediated by psychological empowerment.

H7: Relationship between pay satisfaction and organisational commitment is partially mediated by psychological empowerment.

\section{Research Methodology}

The population for this study comprised 6276 academic staff from selected universities obtained from Department of Academic Affairs from the respective universities. Krejcie and Morgan's table suggested that when the population is 6276, the targeted sample size should be 364 (Krejcie \& Morgan, 1970). A total of 400 self-administered questionnaires were distributed to the respondents using a simple random sampling method and a total of 297 questionnaires were returned, which make up a response rate of $74.2 \%$.

The respondents in the study were academic staff located in northern public universities in Malaysia who represented various categories such as lecturers, senior lecturers, associate professors, and professors. The questionnaires comprised 11 items examining respondents' commitment developed by Meyer and Allen (1991; 1997), nine items assessing respondents' work stress level from Cartwright and Cooper (2002), and Kelloway and Barling (1994), nad 10 items relating to psychological empowerment developed by Ashforth (1989), Hackman and Oldham (1980), Jones (1986), Spreitzer (1995), and Tymon (1988). The respondents indicated the extent to which they agreed with each statement on a five-point scale, ranging from; (1) Strongly disagree to (5) Strongly agree. For pay satisfaction, nine items were utilised to assess level of respondents' pay satisfaction and the instrument was adapted from Comm and Mathaisel (2003), Heneman and Schwab (1985), and Price and Mueler (1986). A Likert five-point scale ranging from (1) Very dissatisfied to (5) Very satisfied was employed 
to measure the pay satisfaction level of respondents. Analysis of data was done using statistical analysis (SPSS version 21.0). Descriptive statistics were used to simplify and characterise the data. Further analysis included factor analysis, correlation, and regression to test the hypotheses.

\section{Findings}

\section{Respondent Profile}

Out of the 297 respondents, $54.2 \%$ were female and $45.8 \%$ were male. Most of the respondents hold a Master degree while the rest have $\mathrm{PhD}$ and Bachelor degrees. The majority of them have one to five years' were experience. In terms of marital status, $73 \%$ were married and $27 \%$ were single.

\section{Exploratory Factor Analysis}

The data were analysed using exploratory factor analysis with principal axis factoring for variables with dimensions, which are organisational commitment and psychological empowerment. Kaiser-Meyer Olkin (KMO) measure of sampling adequacy suggested that the sample was factorable $(\mathrm{KMO}=.72)$. The results of Varimax rotation of the solution for organisational commitment are shown in Table 1. This solution explained $16.42 \%$ of the variance. Four items loaded onto Factor 1 which was labeled as affective commitment. Subsequent iterations were performed following deletion of cross-loaded items based on .30 as the cut-off criterian or items that were theoretically inconsistent with their factor (Hair, Black, Babin, \& Anderson, 2010). One item with factor loading of less than .30 was deleted; "Jumping from organisation to organisation does not seem at all unethical to me". Two items were loaded onto Factor 2, and labelled as continuance commitment which accounted for $13.78 \%$ of the variance. One item was deleted; "I am not afraid of what might happen if I quit my job without having another lined up", whilst Factor 3 consisted of 3 items and relates to normative commitment and accounts $5.39 \%$ of the variance.

Next, the results of an exploratory factor analysis for psychological empowerment are shown in Table 2. This solution explained $37.78 \%$ of the variance and included three items loaded onto Factor 1, which was labelled as competence. Four items were loaded onto Factor 
2, labelled as impact and accounted for $14.38 \%$ of the variance. While Factor 3 consisted of two items and relates to meaning, and accounted $9.36 \%$ of the variance. For Factor 4 , it was labelled as selfdetermination and only one item was loaded onto this factor, and accounted for $4.31 \%$ of the variance.

Table 1

Factor Analysis for Items in Organisational Commitment $(N=297)$

\begin{tabular}{lcc}
\hline $\begin{array}{l}\text { Item } \\
\text { code }\end{array}$ & Item & $\begin{array}{c}\text { Factor } \\
\text { loading }\end{array}$ \\
\hline
\end{tabular}

Factor 1: Affective

B6 It would be very hard for me to leave my organisation right now, if I want to

B7 I feel that I have too few options to consider leaving this organisation

B8 It will be too costly for me if I leave my organisation

B9 I think that people these days move from one company to another too often

B11 Jumping from organisation to organisation does not seem at all unethical to me

Percentage of variance explained

\section{Factor 2 : Continuance}

B1 I would be very happy to spend the rest of my career with this organisation

B2 I enjoy discussing my organisation with people outside $\quad .90^{*}$

B5 I am not afraid of what might happen if I quit my job without having another lined up

Percentage of variance explained

\section{Factor 3: Normative}

B3 I do not feel like "a part of the family" at my organisation

B4 This organisation has a great deal of personal meaning for me

B10 I do not believe that a person must always be loyal to his or her organisation 
IJMS 23 (1), 51-72 (2016)

Table 2

Factor Analysis for the Items in Psychological Empowerment $(N=297)$

\begin{tabular}{|c|c|c|}
\hline $\begin{array}{l}\text { Item } \\
\text { code }\end{array}$ & Item & $\begin{array}{l}\text { Factor } \\
\text { loading }\end{array}$ \\
\hline & Factor 1: Competence & \\
\hline F5 & My job is well within scope of my abilities & $.56^{*}$ \\
\hline F6 & I am confident about my ability to do my job & $.87^{*}$ \\
\hline \multirow[t]{3}{*}{ F7 } & I have mastered the skills necessary for my job & $.85^{*}$ \\
\hline & Percentage of variance explained & 37.78 \\
\hline & Factor 2 : Impact & \\
\hline F4 & $\begin{array}{l}\text { I have considerable opportunities of independence and } \\
\text { freedom in performing my job }\end{array}$ & $.54^{*}$ \\
\hline F8 & $\begin{array}{l}\text { I have a great deal of control over what happens in my } \\
\text { faculty }\end{array}$ & $.86^{*}$ \\
\hline F9 & My impact on what happens in my faculty is large & $.46^{*}$ \\
\hline \multirow[t]{3}{*}{ F10 } & $\begin{array}{l}\text { I have significance influence over what happens in my } \\
\text { faculty }\end{array}$ & $.63^{*}$ \\
\hline & Percentage of variance explained & 14.38 \\
\hline & Factor 3: Meaning & \\
\hline F1 & My job activities are personally meaningful to me & $.81^{*}$ \\
\hline \multirow[t]{3}{*}{$\mathrm{F} 2$} & The work I do so is very important to me & $.79^{*}$ \\
\hline & Percentage of variance explained & 9.36 \\
\hline & Factor 4: Self-determination & \\
\hline \multirow[t]{2}{*}{ F3 } & I can decide on my own how to go about doing my work & $.84^{*}$ \\
\hline & Percentage of variance explained & 4.31 \\
\hline
\end{tabular}

\section{Descriptive Analysis and Correlation}

Table 3 shows that the result of descriptive statistics, Cronbach's alpha values and correlation of the variables. The mean range for all variables is positive and mostly agree range at $3.24-3.68$. The reliability values showed the alpha value for each variable in the range between .70 and .82 which had exceeded the recommended value .50 , as suggested by Hair et al. (2010). The range of correlation among the constructs was from .34 to .46 , which are at accepted levels and meet the requirements. 
IJMS 23 (1), 51-72 (2016)

Table 3

Means, Reliability Coefficients, and Correlations

\begin{tabular}{lcccccc}
\hline Variables & $\begin{array}{c}\text { Mean Cronbach's } \\
\text { Alpha }\end{array}$ & $\mathbf{1}$ & $\mathbf{2}$ & $\mathbf{3}$ & $\mathbf{4}$ \\
\hline Work Stress & 3.24 & .73 & 1 & & & \\
Pay Satisfaction & 3.37 & .81 & $-.468^{* *}$ & 1 & & \\
Psychological Empowerment & 3.68 & .82 & $-.340^{* *}$ & $.466^{* *}$ & 1 & \\
Organisational Commitment & 3.38 & .70 & $-.406^{* *}$ & $.418^{* *}$ & $.455^{* *}$ & 1 \\
\hline ** Correlation is significant at the level 0.01 level (2-tailed) & & &
\end{tabular}

\section{Hypothesis Testing}

The multiple regression analysis determines which variables (independent variables) explain variability in the outcome, how much variability in the dependent variable is explained by the independent variables, and which variables are significant.

Table 4

Summary of Multiple Regression Analysis

\begin{tabular}{lcccccccc}
\hline \multicolumn{1}{c}{ Construct } & $\begin{array}{c}\text { Dependent } \\
\text { variable }\end{array}$ & $\mathbf{R}^{\mathbf{2}}$ & $\mathbf{F}$ & $\begin{array}{c}\text { Std. Error of } \\
\text { the Estimate }\end{array}$ & Beta & t-value & Sig. & Decision \\
\hline Work stress & $\begin{array}{c}\text { Organisational } \\
\text { commitment }\end{array}$ & .214 & 27.794 & .33009 & -.396 & -6.339 & .000 & H1 Accepted \\
Pay satisfaction & & & & & .161 & 2.292 & .023 & H2 Accepted \\
$\begin{array}{l}\text { Psychological } \\
\text { empowerment }\end{array}$ & & & & & .274 & 4.303 & .000 & H3 Accepted \\
\hline Work stress & $\begin{array}{c}\text { Psychological } \\
\text { empowerment }\end{array}$ & .340 & 77.309 & .50901 & .107 & 1.883 & .061 & H4 Rejected \\
Pay satisfaction & & & & & .521 & 9.156 & .000 & H5 Accepted \\
\hline
\end{tabular}

Table 4 shows that work stress, pay satisfaction, and psychological empowerment have significant impact on organisational commitment at $p<.05$. The results also showed that pay satisfaction has a significant impact on psychological empowerment ( $\mathrm{p}<.05)$. Hence, H1, H2, H3, and $\mathrm{H} 5$ are supported. However, $\mathrm{H} 4$ was rejected due to significant at $\mathrm{p}>.05$. Consequently, $\mathrm{H} 6$ which is to test the mediating effect of psychological empowerment between work stress and organisational commitment could not be tested because of the insignificant impact between work stress and psychological empowerment. 


\section{Test of Mediating Variable}

The result showed that the IV (pay satisfaction) is significantly related to DV (organisational commitment) $(\beta=0.418, p<0.05$ ), which indicates that Step 1 is fulfilled. Next, the result showed that the IV (pay satisfaction) is also significantly related to MV (psychological empowerment) $(\beta=0.466, p<0.05)$, which indicates that Step 2 is fulfilled. Next in Step 3, the effect of the IV (pay satisfaction) must be controlled; such as the IV (pay satisfaction) and MV (psychological empowerment), and are regressed together against the DV (organisational commitment). The results showed that MV (psychological empowerment) $(\beta=0.333, p<0.05)$, was significant which indicates that Step 3 is fulfilled. As suggested by Baron and Kenny (1986), and Judd and Kenny (1981), Step 4 is to ascertain whether full mediation or partial mediation has occurred. The IV (pay satisfaction) $(\beta=0.263, p<0.05)$ is still significant but the beta value has decreased. It can be drawn that partial mediation has taken place. The summary of multiple regressions analysis is shown in Table 5. In conclusion, psychological empowerment has partially mediated the relationship between pay satisfaction and organisational commitment.

Table 5

Summary of Regression Analysis for Mediating Test

\begin{tabular}{lccc}
\hline & \multicolumn{2}{c}{$\begin{array}{c}\text { Dependent }=\text { Organisational } \\
\text { Commitment }\end{array}$} & Conclusion \\
\cline { 2 - 3 } & Without Mediator & With Mediator & \\
\hline Pay satisfaction & $0.418^{* *}$ & $0.263^{* *}$ & Partial Mediation \\
Psychological & $0.333^{* *}$ & \\
empowerment & & \\
\hline ** Correlation is significant at the 0.05 level (2-tailed). &
\end{tabular}

\section{Discussion}

The findings of this study add knowledge to the existing literature. The current finding is in line with previous studies by Khairuddin and Makhbul (2011), Malik et al. (2010), Mustapha (2013), Onn (2012), and McShane and Von Glinow (2010), which showed work stress, pay satisfaction, and psychological empowerment are significantly related to organisational commitment. It was shown that work stress, 
pay satisfaction, and psychological empowerment are important factors of enhancing organisational commitment among academic staff in the Malaysian setting. The finding also showed that pay satisfaction has significant impact on psychological empowerment. There is little evidence to confirm that pay satisfaction is significantly associated with psychological empowerment. However, Disch et al. (2004), and Gkorezis and Petridou (2011) mentioned that if employees believed and were satisfied with the rewards and benefits, they would often feel deep meaning and connected with their work. Therefore, employees feel more empowered if they receive high reward from their organisation. Besides, the results indicated that work stress is not a good predictor of psychological empowerment. Individuals who are highly stressed will never give impact on meaning and selfdetermination toward their job. This means that when employees feel highly stressed, they will feel that organisation does not give any meaning and is not concerned them. Further, the result of mediating variable showed that the relationship between pay satisfaction and organisational commitment is partially mediated by psychological empowerment. A possible explanation for these findings is that when academic staff are satisfied with the pay received, they feel that they are important to the organisation. Therefore, they are motivated to improve commitment, job performance, and go beyond expectations. Furthermore, past studies argued that organisations that are concerned in empowering their employees and making committed workforce should develop a system which would reward employees' performance accordingly.

\section{Conclusion}

Based on the findings, it can be concluded that work stress, pay satisfaction, and psychological empowerment are significant predictors of organisational commitment. It was also found that providing high extrinsic reward could lead to high intrinsic reward to make employees feel that they are important to the organization, and motivate employees to give more effort to the organisation. So policy makers and academic administrators should take necessary actions for the ideal provision of intrinsic and extrinsic job rewards to motivate employees to be highly satisfied and committed to gain the benefits of improved motivation and performance.

Similar to other studies, this study also has some limitations. Firstly, this study focused on academic staff; future research could further extend to non-academic staff as well. Secondly, the sample size was 
too small which focused on northern region area. Future research should employ a much larger sample size and focus on the whole nation of Malaysia. Thirdly, a cross-sectional strategy was employed for this survey. Future study could look into and employ a longitudinal strategy. In addition, the researcher also recommended a few other approaches to be undertaken by identifying other factors that affect stress at the work place, such as work-life balance, job overload, job security, pay and benefits, communication, and work conflict that may also affect employees' commitment toward the organisation.

\section{References}

Adebiyi, D. R. (2013). Occupational stress among academic staff of Ekiti State University, Ado-Ekiti. European Scientific Journal, 9(4), 202-208.

Ashari, H., Ahmad, U. N. U., \& Rahman, S. A. A. (2005). Organisational commitment among academicians: Its relationship with stress level. Universiti Teknologi Malaysia.

Ashforth, B., E. (1989). The experience of powerlessness in organisations. Organisational Behavior and Human Decision Processes, 43, 207-242.

Awang, Z., \& Ahmad, J. H. (2010). Modelling job satisfaction and work commitment among lecturers: A case of UiTM Kelantan. Proceedings of the Regional Conference on Statistical Sciences 2010 (RCSS'10), June 2010, 241-255.

Barkhuizen, N., Roodt, N., \& Schutte, N. (2014). Talent management of academics: Balancing job demands and job resources. Mediterranean Journal of Social Sciences, 5(20), 2033-2038.

Baron, R. M., \& Kenny, D. A. (1986). The Moderator-mediator variable distinction in social psychological research: Conceptual, strategic and statistical considerations. Journal of Personality and Social Psychology, 51, 1173-1182.

Bogler, R., \& Somech, A. (2004). Influence of teacher empowerment on teachers' organisational commitment, professional commitment and organisational citizenship behaviour in schools. Teaching and Teacher Education, 20, 277-289.

Bowen, D., \& Lawler, E. (1992). The empowerment of service workers: What, why, how, and when. Sloan Management Review, 33(3), 31-39.

Carless, S. A. (2004). Does psychological empowerment mediate the relationship between psychological climate and job satisfaction? Journal of Business and Psychology, 18, 405-425. 
Cartwright, S., \& Cooper, C. L. (2002). ASSET: The management guide. Manchester: Robertson Cooper Limited.

Chang, J., \& Choi, J. (2007). The dynamic relation between organisational and professional commitment of highly educated research and development professional. The Journal of Social Psychology, 147(3), 299-315.

Chen, H. F., \& Chen, Y. C. (2008). The impact of work redesign and psychological empowerment on organisational commitment in a changing environment: An example from Taiwan's stateowned enterprises. Public Personnel Management, 37(3), 279-302.

Chen, S., Lin, P., Lu, C., \& Taso, C. (2007). The moderation effect of the strength on the relationship between employee commitment and job performance. Social Behaviour and Personality, 35(8), $1121-1138$

Comm., C. L., \& Mathaisel, D. F. X. (2003). A case study of the implications of faculty workload and compensation for improving academic quality. The International Journal of Educational Management, 17, 200-210.

Conger, J. A., \&Kanungo, R. N. (1988). The empowerment process: Integration theory and practice. Academy of Management Journal, 13(3), 471-482.

Dee, J. R., Henkin A. B., \& Duemer L. (2003). Structural antecedents and psychological correlates of teacher empowerment. Journal of Educational Administration, 41(3), 257-277.

Disch, J., Edwardson, S., \& Adwan, J. (2004). Nursing faculty satisfaction with individual, institutional, and leadership factors. Journal of Professional Nursing, 20(5), 323-331.

Dulebohn, J. H., \& Martocchio, J. J. (1998). Employee perceptions of the fairness of work group incentives pay plans. Journal of Management, 24(4), 469-488.

Fornes, S. L., \& Rocco, T. S. (2004). Commitment elements reframed (antecedents and consequences) for organisational effectiveness. Florida International University, 19(3), 391-397.

French, J. R. P., Jr., Caplan, R. D., \& Harrison, R. V. (1982).The mechanisms of job stress and strain. London: Wiley.

Freund, A. (2005). Commitment of job satisfaction as predictors of turnover intentions among welfare workers. Administration in Social Work, 29(2), 5-21.

Galletta, M., Portoghese, I., \& Battistelli, A. (2011). Intrinsic motivation, job autonomy, and turnover intention in the Italian healthcare: The mediating role of affective commitment. Journal of Management Research, 3(2), 1-19. 
Gardner, D. G., van Dyne, L., \& Pierce, J. L. (2004). The effects of pay level on organisation-based self-esteem and performance: A field study. Journal of Occupational and Organisational Psychology, 77, 307-322.

Gillespie, N. A., Walsh, M., Winefield, A. H., Dua, J., \& Stough, C. (2001). Occupational stress in universities: Staff perceptions of the causes, consequences, and moderators of stress. Work and Stress, 15, 53-72.

Gkorezis, P., \& Petridou, E. (2011). The impact of extrinsic rewards on nurses' psychological empowerment: The case of health care in Greece. Health Service Management Research, 24(2), 55-59.

Gupta, M., \&Gehlawat, M. (2013). A study of the correlates of organisational commitment among secondary school teacher's issues and ideas in education, 1,59-71.

Hackman, J. R., \& Oldham, G. R. (1980). Development of the job diagnostic survey. Journal of Applied Psychology, 60,159-170.

Hadi, F., Zahra, I., Ismi, A. I., \& Farhad, A. (2015). Relationship between quality of work life and organisational commitment among lecturers in a Malaysian public research university. The Social Science Journal, 52(1), 54-61

Hafiz I., Iqra, A., Sadaf, C., \& Azeem, M. (2014). Relationship between job satisfaction, job performance, attitude towards work, and organisational commitment. Entrepreneurship and Innovation and Management Journal, 2(2).

Hair, J.F., Black, W. C., Babin, B. J., \& Anderson, R. E. (2010). Multivariate data analysis (7th ed). New Jersey: Pearson Prentice Hall.

Heneman, H. G., \& Judge, T. A. (2000). Incentives and motivation. In S. Rynes \& B. Gerhart (Eds.), Compensation in organisations: Progress and prospects (pp. 61-103). San Francisco, CA: New Lexington Press.

Heneman, H. G., \& Schwab, D. P. (1985). Pay satisfaction: Its multidimensional nature and measurement. International Journal of Psychology, 20, 129-141.

Ismail, N. (2012). Organisational commitment and job satisfaction among staff of higher learning education institutions in Kelantan. Unpublished Master Dissertation.Universiti Utara Malaysia.

Jain, K. K., Jabeen, F., Mishra, V., \& Gupta, N. (2007). Job satisfaction as related to organisational climate and occupational stress: A case study of Indian Oil. International Review of Business Research Papers, 3(5), 193-208.

Jones, G. R. (1986). Socialization tactics, self-efficacy, and newcomer's adjustments to organisations. Academy of Management Journal, $29,262-279$. 
Judd, C., M., \& Kenny, D., A. (1981). Process analysis: Estimating mediation in treatment evaluations. Evaluation Review, 5, 602-619.

Kahn, R. L., Wolfe, D. M., Quinn, R. P., Snoek, J. D., \& Rosenthal, R. A. (1964). Organisational stress: Studies in role conflict and ambiguity. New York: Wiley

Kelloway, E. K., \& Barling, J. (1991). Job characteristics, role stress, and mental health. Journal of Occupational Psychology, 64, 291-304.

Khairuddin, S.M.H.S., \& Makhbul, Z.M. (2011). Stress at the workplace and productivity: A pilot study on faculty administrators in a Malaysian Research University. $2^{\text {nd }}$ International Conference on Business and Economic Research ( $\left.2^{\text {nd }} I C B E R\right)$.

Khany, R., \& Tazik, K. (2015). On the relationship between psychological empowerment, trust, and Iranian EFL teacher's job satisfaction: The case of secondary school teachers. Journal of Career Assessment, 1-18.

Krejcie, \& Morgan (1970). Determining sample size for research activities. Educational and Psychological Measurement, 30, 607-610.

Krishna, Y. R. (2007). Psychological empowerment and organisational commitment. The Icfai Journal of Organisational Behavior, 6(4), 26-36.

Laschinger, H. K. S., \& Havens, D. S. (1996) Staff nurse work empowerment and perceived control over nursing practice, work satisfaction and work effectiveness. Journal of Nursing Administration, 26, 27-35.

Laschinger, H. K., Wong, C., MacMahon, L., \& Kaufmann, C. (1999). Leader behaviour impact on staff nurse empowerment, job tension, and work effectiveness. Journal of Nursing Administration, 29 (5) 28-39

Lawler, E. E. (1971). Pay and organisational effectiveness. New York: McGraw-Hill.

Lazarus, R. S. (1991). Emotion and adaptation. Oxford, UK: Oxford University Press.

Lee, A. N., \& Nie, Y. (2014). Understanding teacher empowerment: Teacher's perceptions of principal's and immediate supervisor's empowering behaviours, psychological empowerment and work-related outcomes. Teaching and Teacher Education, 41, 67-79.

Liu, A. M. M., Fellows, R., \& Chiu, W. M. (2006). Work empowerment as an antecedent to organisational commitment in the Hong Kong quantity surveying profession. Surveying and Built Environment, 17(2), 63-72.

Lew, T. Y. (2011). Understanding the antecedents of affective organisational commitment and turnover intention of academics in Malaysia. African Journal of Business Management, 5(7), 2551-2562. 
Malik, M. E., Nawab, S., Naeem, B., \& Danish, R. Q. (2010). Job satisfaction and organisational commitment of University Teachers in Public Sector of Pakistan. International Journal of Business and Management, 5(6), 17-26

McElroy, J. C. (2001). Managing workplace commitment by putting people first. Human Resources Management Review, 11, 327-335.

McShane, S. L., \& Von Glinow, M. A. (2010). Organisational behaviour: Emerging knowledge and practice for the real world, (5th ed.). New York: McGraw-Hill/Irwin.

Meyer, J. P., \& Allen, N. J. (1987). A longitudinal analysis of the early development and consequences of organisational commitment. Canadian Journal of Behavioural Science, 19, 199-215.

Meyer, J. P., \& Allen, N. J. (1991). A three-component conceptualization of organisational commitment. Human Resource Management Review, 1, 61-89.

Meyer, J. P., \& Allen, N. J. (1997). Commitment in the workplace: Theory, research, and application. Thousand Oaks, CA: Sage Publications.

Michael, O., Court, D., \& Petal, P. (2009). Job stress and organisational commitment among mentoring coordinators. International Journal of Educational Management, 23(3), 266- 288.

Milkovich, G. M., \& Newman, J. M. (2004). Compensation ( $8^{\text {th }}$ ed.). Burr Ridge, IL: Irwin McGraw-Hill.

MoHE (2012). In Komoo, I., Azman, N., \& Aziz, Y. F. A. Malaysian research universities and their performance indicators. Bulletin of Higher Education Research, 11, 5-7

Mustapha, N. (2013). The influence of financial reward on job satisfaction among academic staffs at public universities in Kelantan, Malaysia. International Journal of Business and Social Science, 4(3), 244-248

Nabila, A. A. (2008). The relationship between psychological empowerment and organisational commitment: A case study among employees in construction sector in Kota Kinabalu, Sabah. Unpublished Master Thesis, School of Business and Economic, UMS.

Newstrom, J. W., \& Davis, K. (2002). Organisational behaviour. Human behaviour at work (11th ed.). Tata, New Delhi: McgrawHill Publishing Company Limited.

Nilufar, A., Abdullah, Z., Fie, D. Y. G., \& Alam, S. S. (2009). A study of job stress on job satisfaction among university staff in Malaysia: Empirical study. European Journal of Social Sciences, 8(1), 121-131.

Noordin, F., \& Jusoff, K. (2009). Levels of job satisfaction amongst Malaysian academic staff. Journal of Asian Social Science,5(5). 
Noraida, S. S. Z. A., Shaladdin, M. M., Fauziah, A. H., \& Munir, A. M. S. (2010). Organisational commitment in Malaysian public sector. International Journal of Management Studies, 17(1), 107-128.

Obeng, K., \& Ugboro, I. (2003). Organisational commitment among public transit employees: An assessment study. Journal of Transportation Research Forum, 57(2), 83-98.

O'Laughlin, E. M., \& Bischoff, L. G. (2005). Balancing parenthood and academia: Work/family stress as influenced by gender and tenure status. Journal of Family Issues, 26(1), 79-106

Onn, C. Y. (2012). Antecedents of organisational commitment amongst academic staff of private universities in Malaysia. Master Thesis, Universiti Tunku Abdul Rahman.

Price, J. L., \& Mueller, C. W. (1986). Handbook of organisational measurement. Cambridge, MA: Ballinger.

Purvanova, R. K., \& Muros, J. P. (2010). Gender differences in burnout: A meta-analysis. Journal of Vocational Behaviour, 77, 168-185.

Selye, H, (1976). The stress of life. New York: McGraw-Hill.

Sheldon, M. E. (1971). Investments and involvements as mechanisms producing commitment to the organisation. Administrative Science Quarterly, 16,143-150.

Siddique, A., Aslam, H. D., Khan, M., \& Fatima, U. (2011). Impact of academic leadership on faculty's motivation, and organisational effectiveness in higher education system. International Journal of Business and Social Science, 2(8), 184-191.

Solomon, L., \& Podgursky, M. (2001).The pros and cons of performance-based compensation.Milken Family Foundation, Pascadena.

Spreitzer, G. M. (1995). Psychological empowerment in the workplace: Dimensions, measurement, and validation. Academy of Management Journal, 38(5), 1442-1465.

Takleab, A. G., Takeuchi, R., \& Taylor, M. S. (2005). Extending the chain of relationships among organisational justice, social exchange, and employee reactions: The role of contact violations. Academy of Management Journal, 48(1), 146-157.

Tella, C. O., Ayeni S. O., \& Popoola (2007).Work motivation, job satisfaction, and organisationalcommitment of library Personnel in Academic and Research Libraries in Oyo State, Nigeria. Library Philosophy and Practice.

Terpstra, E., Honoree, \& Andree, L. (2003). The relative importance of external, internal, individual, and procedural equity to pay satisfaction. Compensation and Benefits, 35(6), 67-74. 
Thomas, K. W., \& Tymon, W. G., Jr. (1994). Does empowerment always work: Understanding the role of intrinsic motivation and personal interpretation. Journal of Management Systems, 6(2), 1-13.

Thomas, K. W., \& Velthouse, B. A. (1990). Cognitive elements of empowerment: An interpretive model of intrinsic task motivation. Academy of Management Review, 15, 666-681.

Tremblay, M. S., Inman, J. W., \& Willms, J. D. (2000). The relationship between physical activity, self-esteem, and academic achievement in 12-Year-Old Children. Pediatric Exercise Science, 12, 312-324.

Tymon, W. G., Jr. (1988). An empirical investigation of a cognitive model of empowerment. Doctoral dissertation, Temple University.

Vandenberghe, C., \& Tremblay, M. (2008). The role of pay satisfaction and organisational commitment in turnover intentions: A twosample study. Journal of Business and Psychology, 22, 275-286.

Wang, G., \& Lee, P. D. (2009). Psychological empowerment and job satisfaction: An analysis of interactive effect. Group and Organisation Management, 34, 271-296. 